\title{
Indicators of movement and space use for two co-occurring invasive crayfish species
}

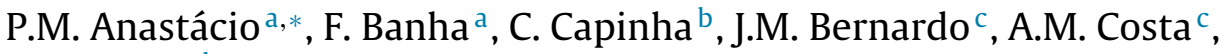 \\ A. Teixeira ${ }^{\mathrm{d}}, \mathrm{S}$. Bruxelas ${ }^{\mathrm{e}}$ \\ a MARE - Marine and Environmental Sciences Centre, Departamento de Paisagem, Ambiente e Ordenamento, Escola de Ciências e Tecnologia, \\ Universidade de Évora, Rua Romão Ramalho 59, 7000-671 Évora, Portugal \\ b CIBIO/InBio, Campus Agrário de Vairão, Rua Padre Armando Quintas n 7, 4485-661 Vairão, Portugal \\ c Departamento de Paisagem, Ambiente e Ordenamento, Escola de Ciências e Tecnologia, Universidade de Évora, Rua Romão Ramalho 59, \\ 7000-671 Évora, Portugal \\ d CIMO-ESA-IPB, Mountain Research Centre, School of Agriculture, Polytechnic Institute of Bragança, Campus de Sta Apolónia, Apartado 1172, \\ 5300-855 Bragança, Portugal \\ e Instituto da Conservação da Natureza e das Florestas, I.P., Avenida da República 16, 1050-191 Lisboa, Portugal
}

\section{A R T I C L E I N F O}

\section{Article history:}

Received 12 June 2014

Received in revised form

23 December 2014

Accepted 9 January 2015

\section{Keywords:}

Radio-tracking

Biological invasions

Dispersal

Iberian Peninsula

River

Crustacea

\begin{abstract}
A B S T R A C T
Red swamp crayfish (Procambarus clarkii) and signal crayfish (Pacifastacus leniusculus) are two invasive freshwater species with a worldwide distribution. The objective of this work was to investigate how the two species move and use space in an area of recent coexistence. Simultaneously, we test the use of new tools and indices to describe their movement patterns. To accomplish this we performed a radiotracking program within a river-type habitat during two different periods (September/October 2010 and June/July 2013). We used spatial analysis tools to map crayfish radio-location data with and without accounting for the curvature of the river. To assess the consistency of the direction of movement and of the distances traveled by crayfish, two indices were developed. To assess the habitat preferences of each species we applied Ivlev's Electivity Index and the Standardized Forage Ratio. Movement of $P$. clarkii and $P$. leniusculus differed. The average detected movement was $8.8 \mathrm{~m} \mathrm{day}^{-1}$ for $P$. clarkii and $17.5 \mathrm{~m} \mathrm{day}^{-1}$ for $P$. leniusculus. However, crayfish behavior ranged from almost complete immobility - sometimes during several days - to large movements, in half a day, up to a maximum of $255 \mathrm{~m}$ for P. clarkii and $461 \mathrm{~m}$ for $P$. leniusculus. The proportion of upstream or downstream movements was independent of the species and both species displayed no preference for either direction. The indices of consistency of movement showed a large interindividual variation. Species and period (2010 or 2013) affected the mean daily distance traveled, maximum observed distance from location of release and percentage of observations under vegetation cover. The Ivlev's Electivity Index and the Standardized Forage Ratio presented similar results. $P$. clarkii showed a preference for pool areas with riparian vegetation cover while $P$. leniusculus preferred riffle and pool areas with riparian vegetation cover. Our work provided new and valuable data for modeling the active dispersal of these two problematic invaders in a context of coexistence.
\end{abstract}

(C) 2015 Elsevier Ltd. All rights reserved.

\footnotetext{
* Corresponding author: MARE - Marine and Environmental Sciences Centre, Departamento de Paisagem, Ambiente e Ordenamento, Escola de Ciências e Tecnologia, Universidade de Évora, Rua Romão Ramalho 59, 7000-671 Évora, Portugal. Tel.: +351266745385.

E-mail addresses: anast@uevora.pt (P.M. Anastácio), filipebanha@hotmail.com (F. Banha), cesarcapinha@outlook.com (C.Capinha),jmb@uevora.pt (J.M. Bernardo), amac@uevora.pt (A.M. Costa), amilt@ipb.pt (A. Teixeira), Sofia.Bruxelas@icnf.pt (S. Bruxelas)
}

\section{Introduction}

Due to their economic value, several species of crayfish were introduced outside their native ranges. Unfortunately there are numerous freshwater crayfish species becoming invasive in the areas of introduction (Holdich, 1988; Henttonen and Huner, 1999; Gherardi, 2013) and the two major examples are the red swamp crayfish (Procambarus clarkii) and the signal crayfish (Pacifastacus leniusculus). Both species now have very large invasive ranges worldwide and further spread is expected since there are still wide areas of the planet with adequate environmental conditions (Capinha et al., 2011). 


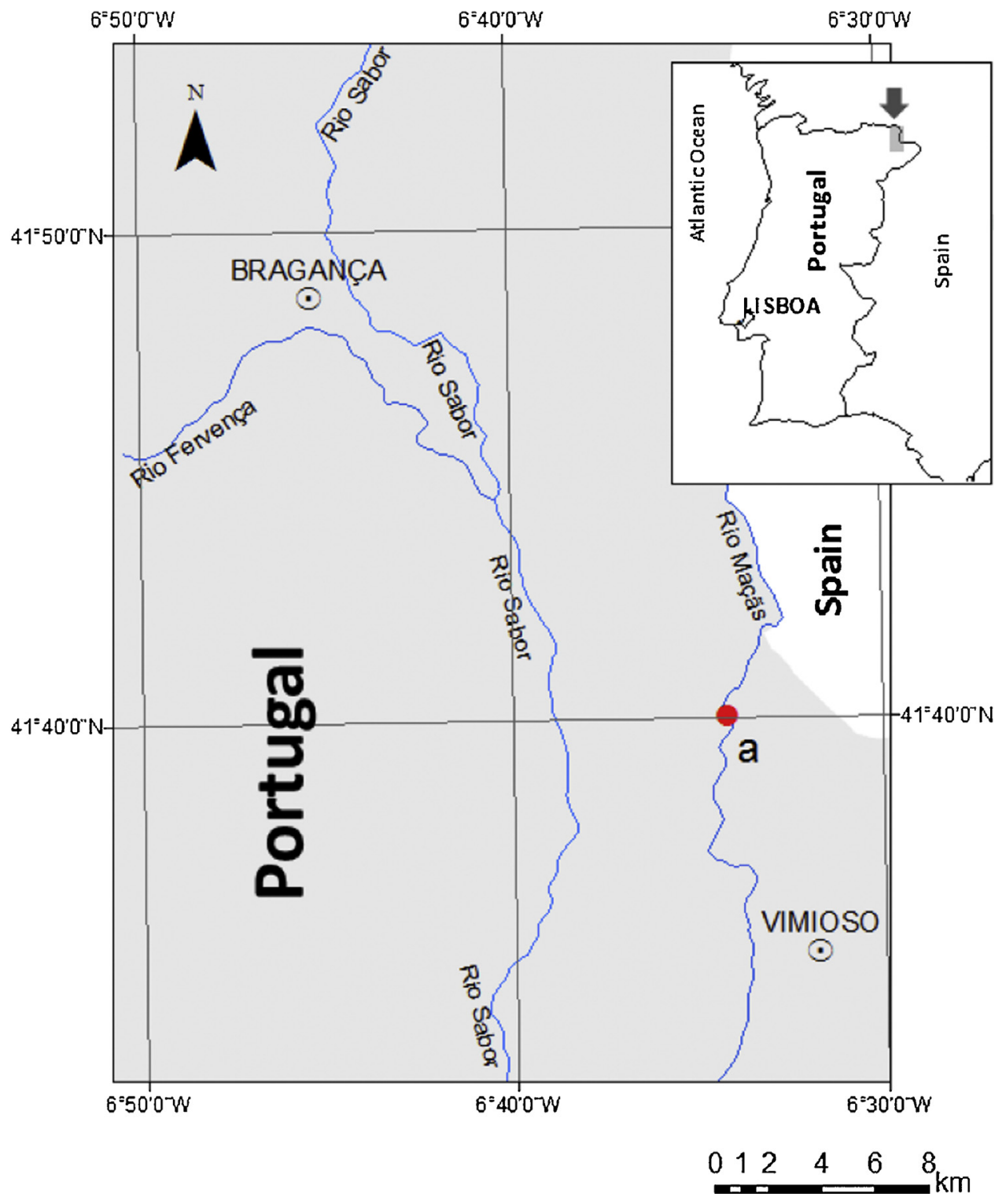

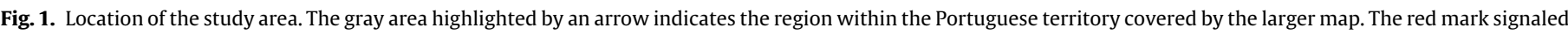

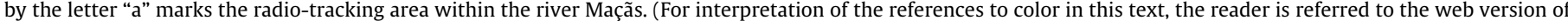
the article.)

The red swamp crayfish is native to subtropical regions of northeastern Mexico and south-central USA. This species has a highly plastic reproductive cycle (Gherardi, 2006) and a wide ecological plasticity (Gherardi, 2006; Souty-Grosset et al., 2006) and currently it is the most widely introduced crayfish in the world (Gherardi, 2006). In Europe the species was first introduced in 1973 in southern Spain (Habsburgo-Lorena, 1978) and it rapidly spread across several European countries (Laurent, 1997; Souty-Grosset et al., 2006) showing the widest invasive range for an alien crayfish.

The signal crayfish is native from the cool temperate regions of Western North America and it is endemic to Western North America between the Pacific Ocean and the Rocky Mountains. Its habitat ranges from lotic to lentic systems but it is able to tolerate exposure to brackish water (Lowery and Holdich, 1988; Lewis, 2002). P. leniusculus was first introduced to northern Europe in the 1960s to replace decreasing stocks of the native Astacus astacus (Abrahamsson, 1973; Westman, 1973). Currently this is the most widespread invasive crayfish in Europe, being present in 27 countries (Holdich et al., 2010).
Invasive crayfish affect not only the distribution of native crayfish but also the dynamics and biodiversity of the invaded community (Gherardi and Holdich, 1999; Gherardi, 2006; Holdich et al., 2010). Both $P$. clarkii and P. leniusculus are responsible for multiple negative impacts on native species, ecosystems and economic activities in the new ranges. However, these new arrivals increased the commercial value of crayfish in Europe and in many other parts of the world (Nyström, 1999; Souty-Grosset et al., 2006).

On a macroscale, human introductions and environmental suitability can successfully explain the distribution of $P$. clarkii and P. leniusculus in Europe (Capinha et al., 2013). However, the local spread and progression of the invasion fronts within or even across country borders needs to be addressed if mitigation, management or containment actions are to be implemented. Several authors studied the progression of the invasion front or the movement patterns of each of these species (e.g. Bubb et al., 2004; Aquiloni et al., 2005; Kerby et al., 2005; Bernardo et al., 2011; Almeida et al., 2013; Johnson et al., 2014) but not the coexistence of the two species. $P$. clarkii and $P$. leniusculus have distinct but nevertheless overlapping 
environmental niches (Capinha and Anastácio, 2011). As each of these species expands its invasive range, the areas of coexistence became wider and therefore some interactions may occur, potentially affecting the patterns of space use and speed of the invasion front. In fact, within the Iberian Peninsula, there are already some areas of coexistence of both species and some effort is being conducted to document on a regional scale how the spread of these two species is affected by this coexistence (Bernardo et al., 2011).

There are several software tools for analyzing movement and space distribution of terrestrial species that process data collected by radio-tracking. However, river systems have a linear structure and are therefore inadequately approached by some of these tools. One of the problems is the deficient calculus of the distances when a river has a strongly curvilinear shape. Another difficulty concerns the mostly two-way directionality of the movement. Our objective is to find out how the two invaders move and use space in an area of recent coexistence while simultaneously testing the use of new indices for describing the patterns of movement in river systems.

\section{Methods}

During the months of September/October 2010 and June/July 2013 a radio-tracking program was undertaken within a shallow $1330 \mathrm{~m}$ stretch of the river Maçãs, Trás-os-Montes, NE Portugal (Fig. 1), between two adjacent small dams. This stretch has a relatively recent population of both the red swamp crayfish and the signal crayfish (Bernardo et al., 2011).

\subsection{Mesohabitat mapping}

River shape, mesohabitat types and vegetation cover were mapped (Fig. 2) by combining detailed in situ cartographic measurements with aerial imagery ( $1 \mathrm{~m}$ resolution) available from the software ArcMap 10.1. Vegetation cover was mapped as "presence" or "absence" and referred to riparian canopy or to any kind of emergent vegetation. This included trees, shrubs and aquatic macrophytes, without species identification. Water speed was measured using the float method (Meals and Dressing, 2008). Mesohabitats were classified as pools, riffles and runs according to current velocity and turbulence, which was visually assessed. Correspondence of the observed mesohabitat types to Newson and Newson (2000) surface flow types is as follows. Pools: no perceptible flow, smooth surface, reflections with no or very minor distortion; Runs: smooth boundary turbulent flow (very little surface turbulence, very small turbulent flow cells are visible, reflections are distorted); Riffles: rippled flow (water surface has regular disturbances, which form low transverse ripples across the direction of flow), broken standing waves (standing waves present which break at the crest originating white waters), chute flow (fast flow over boulders and bedrock). Pools had a mean speed of zero (i.e. undetected movement), runs had a mean speed of $0.05 \mathrm{~m} \mathrm{~s}^{-1}$ and riffles presented a mean speed of $0.25 \mathrm{~m} \mathrm{~s}^{-1}$ and turbulence caused by the roughness of the streambed, slope and shallow depth. Six habitat types were defined based on the combinations of mesohabitat and vegetation cover types: Pool without cover, Pool with cover, Run without cover, Run with cover, Riffle without cover and, Riffle with cover.

\subsection{Radio tracking procedures}

Tracking was performed in two periods: September/October 2010 (4 P. clarkii and 8 P. leniusculus) and June/July 2013 (3 P. clarkii and $4 P$. leniusculus). Both species were active during these periods of the year and average water depth was enough for crayfish movement and not too deep for radio-tracking along the whole river

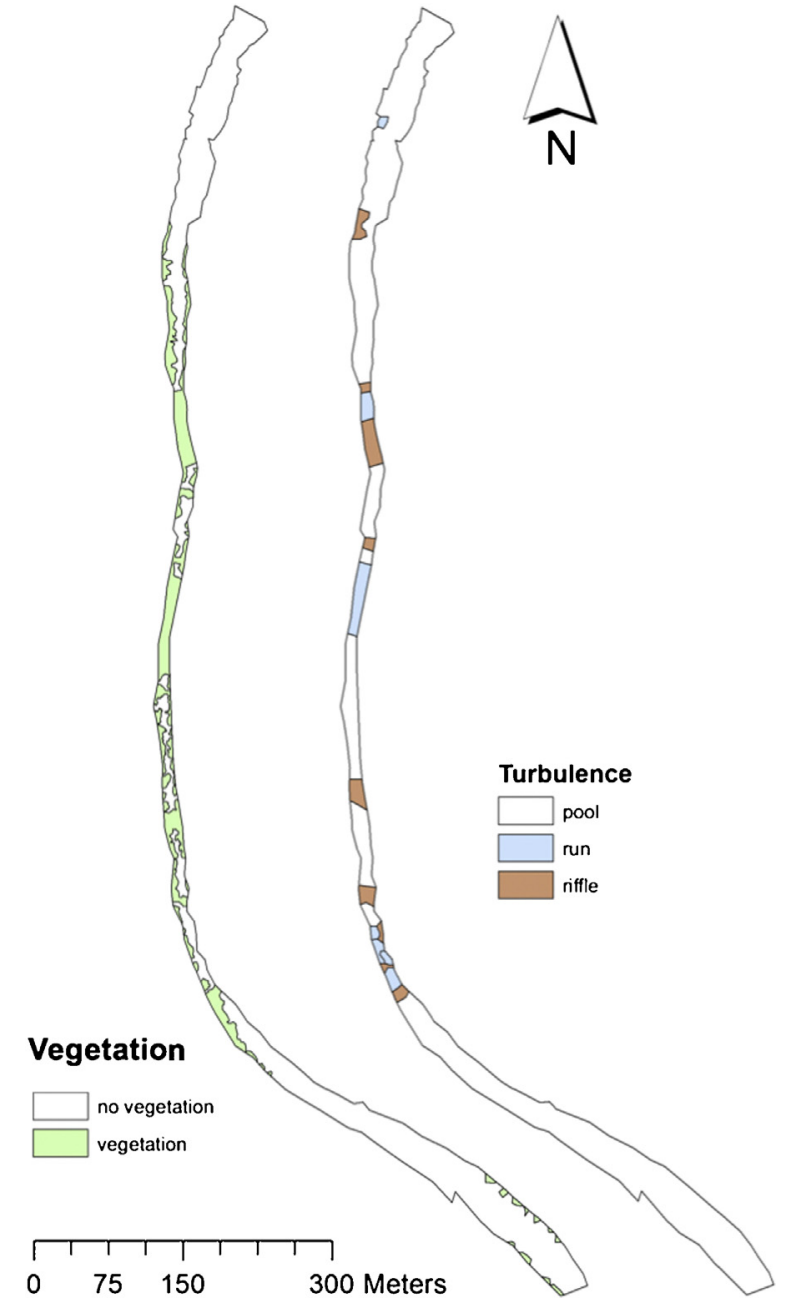

Fig. 2. Vegetation cover and turbulence maps of the studied river stretch. Pools had a mean speed of zero (i.e. undetected movement), runs had a mean speed of $0.05 \mathrm{~m} \mathrm{~s}^{-1}$ and riffles presented a mean speed of $0.25 \mathrm{~m} \mathrm{~s}^{-1}$ and turbulence.

sector. Additionally, during these periods, mesohabitat heterogeneity was large and habitats were accessible to the radio-tracking team moving along the river. $P$. leniusculus total length ranged from 7.7 to $10.9 \mathrm{~cm}$ (mean $=9.76 \mathrm{~cm}$ ) and $P$. clarkii total length ranged from 9 to $10.5 \mathrm{~cm}$ (mean $=9.78 \mathrm{~cm}$ ). In 2010 we used Telenax transmitters model TXB-004G - $150 \mathrm{MHz}$ with on-off magnetic switch $(1.2 \mathrm{~g}, 0.7 \mathrm{~cm} \times 0.8 \mathrm{~cm} \times 1.3 \mathrm{~cm})$ and in 2013 we used Biotrack transmitters (PIP2 single celled tags, with medium potting). Signal reception was assured with a 3 element foldable Yaggi type antenna and a RX-TLNX receiver (both supplied by Telenax). Crayfish were tracked twice a day, at sunrise and sunset, with a $10-30 \mathrm{~cm}$ radius precision for a period of $6-30$ days ( depending on battery life and predation upon crayfish. The distance to the last position, movement direction and distance to each margin of the river were measured. Additionally, each position in the river was registered by a GPS device (Garmin, model Oregon 550t). Water depth and habitat type were recorded whenever a crayfish was located. During each radio-tracking session water variables were measured with a WTW Multiline F-set. In 2010, mean water temperature was $20.4{ }^{\circ} \mathrm{C}(\mathrm{SD} \pm 1.8)$, mean $\mathrm{pH}$ was 7.3 (SD \pm 0.3 ), mean conductivity was $148.1 \mu \mathrm{S} / \mathrm{cm}^{-1}(\mathrm{SD} \pm 14.3)$ and mean dissolved oxygen was $10.4 \mathrm{mg} \mathrm{L}^{-1}(\mathrm{SD} \pm 2.1)$. In 2013 mean water temperature was $25.6^{\circ} \mathrm{C}(\mathrm{SD} \pm 2.1)$, mean $\mathrm{pH}$ was $7.6(\mathrm{SD} \pm 0.4)$, mean conductivity was $109 \mu \mathrm{S} / \mathrm{cm}^{-1}(\mathrm{SD} \pm 2.6)$ and mean dissolved oxygen was $7.06 \mathrm{mg} \mathrm{L}^{-1}(\mathrm{SD} \pm 0.4)$. 


\subsection{Movement distances}

Crayfish radio location data were analyzed on ArcGIS v 10.1, using Hawth's tools 3.27 (Beyer, 2004) and FishTracker (Laffan and Taylor, 2013) for straight line movement analysis and for movement analysis accounting for the curvature of the river, respectively. FishTracker is open source and was written using the ESRI arcpy system. It can calculate least cost paths based on a cost surface map and was originally developed to study fish movements in estuarine systems (Laffan and Taylor, 2013). In our case the cost surface map restricted the movement paths to the river bed area, not allowing for overland movement. We extracted the distances between the consecutive detection points from the geoprocessing log of FishTracker. Based on the recorded movement and direction of movement for each individual, Euclidean distances were obtained using Hawth's tools. These distances were plotted on a circular diagram and analyzed for randomness using Rao's spacing test. The median, range of values and distribution of the pooled distances moved by all crayfish of each species was compared using the Median test, the Moses test of extreme reaction and a Kolmogorov-Smirnov test, respectively.

Mean daily movement of each individual was obtained by dividing the sum of the observed displacement distances (corrected for the curvature of the river using FishTracker) by the number of tracking days.

A MANOVA was applied, where the independent variables were species and year and the dependent variables were mean daily distance traveled, maximum observed Euclidean distance from the point of release and the percentage of observations under vegetation cover for each individual. A LOG $_{10}$ transformation was applied to the variables: mean daily distance and maximum observed distance from the point of release and the assumptions of MANOVA were statistically tested and were not violated. After the MANOVA, an ANOVA was applied to each dependent variable. This allowed us to identify which dependent variables were affected by the tested factors.

Statistical analyses on non-circular data were performed using IBM SPSS v.20. Circular data were analyzed using Oriana 4.02.

\subsubsection{Upstream vs. downstream movements}

We used a Chi-Squared test on a contingency table to analyze if the proportion of upstream or downstream movements was independent of the species. To assess the consistency of the movement direction $\left(I_{\mathrm{dir}}\right)$ and of the distances moved $\left(I_{\text {dist }}\right)$ by each crayfish, two indices were developed:

$I_{\text {dir }}=\frac{\left|n_{\text {downstream }}-n_{\text {upstream }}\right|}{\text { Largest } n}$

where $n$ downstream or upstream are the total number of movements in each direction, respectively

$I_{\text {dist }}=\frac{\mid \sum \text { downstream distances }-\sum \text { upstream distances } \mid}{\text { Largest } \sum}$

where the distances are the Euclidian distances between two consecutive detection locations (downstream and upstream, respectively).

\subsubsection{Space use and mesohabitat preferences}

To better evaluate space use by these species, we produced kernel density maps for each individual, showing the size of the areas with more intense pattern of use and also if there was a single area or multiple areas of intense use. The kernel density maps were produced by FishTracker using the accumulated transit raster within the river as the locations, weighted by their transit times (Laffan and Taylor, 2013). This software excluded the possibility of
Table 1

MANOVA results, using species and year as independent variables and the mean daily distance traveled, the maximum observed distance from the point of release and the percentage of observations under vegetation cover as dependent variables.

\begin{tabular}{llrlll}
\hline Effect & Pillai's trace & \multicolumn{1}{l}{$F$} & Hypothesis df & Error df & Sig. \\
\hline Intercept & 0.976 & 173.350 & 3 & 13 & 0.000 \\
Species & 0.594 & 6.338 & 3 & 13 & 0.007 \\
Year & 0.504 & 4.409 & 3 & 13 & 0.024 \\
Species * year & 0.305 & 1.904 & 3 & 13 & 0.179 \\
\hline
\end{tabular}

overland movements between two detection points, always considering the shortest path within the river bed. Kernel density surfaces were masked by the river bed. The 50th and 90th percentile surfaces of the kernel density surface excluding zero values were calculated by the same software and the corresponding areas were extracted. To assess habitat preferences of each individual crayfish, we applied two indices frequently used for food preference but previously used for habitat preferences (e.g. Loughman et al. 2013). These were the Ivlev's Electivity Index (Ivlev, 1961), and the Standardized Forage Ratio (Chesson, 1983) which is more robust. Both are presented below. (i):

Ivlev's electivity index, $E_{i}$ (Ivlev, 1961) adapted for habitat types

$E_{i}=\frac{r_{i}-P_{i}}{r_{i}+P_{i}}$

where $r_{i}$ is the proportion of observations of the individual crayfish in a habitat type $(i)$ and $P_{i}$ is the relative abundance of that habitat in the study area. $E_{i}$ is scaled so that $E_{i}=-1$ corresponds to total avoidance of the habitat type $(i), E_{i}=0$ represents non-selective use of habitat type $(i)$, and $E_{i}=1$ shows exclusive use of habitat type $(i)$.

Standardized Forage Ratio (Chesson, 1983) adapted for habitat types $(i)$ :

$S_{i}=\frac{r_{i} / P_{i}}{\sum_{n=1}^{n}\left(r_{n} / P_{n}\right)}$

where $r_{i}$ and $P_{i}$ are defined as above, and $n$ is the number of habitat types in the study area. The standardized forage ratio as originally presented takes values between 0 and 1 , with $S_{i}=0$ representing avoidance of habitat type $(i)$ and $S_{i}=1$ exclusive use of habitat type (i).

\section{Results}

\subsection{Movement distances}

Pooled movement data of $P$. clarkii and P. leniusculus differed significantly in relation to median, range of values and distributions ( $n=751$ and $p<0.001$ for all tests: median test, Moses test of extreme reaction and Kolmogorov-Smirnov test). The mean movement (for both years) was $8.8 \mathrm{~m} \mathrm{day}^{-1}$ (95\% confidence interval: $2.575-15.025$ ) for P. clarkii and $17.5 \mathrm{~m} \mathrm{day}^{-1}$ (95\% C.I.: 8.554-26.446) for P. leniusculus (Fig. 3). However, crayfish behavior ranged from almost complete immobility, sometimes for several days, to large movements, in a half day period, reaching a maximum of $255 \mathrm{~m}$ for P. clarkii (Fig. 4) and $461 \mathrm{~m}$ for P. leniusculus (Fig. 5), calculated with FishTracker. For the majority of the time there was no crayfish movement between consecutive surveys and this pattern was the same for both species (Fig. 3d). Using values from both years, $P$. clarkii and $P$. leniusculus did not move on $67.6 \%$ and $57.95 \%$ of the half day periods, respectively.

A MANOVA (Table 1) showed that the factors 'species' and 'period' significantly affected crayfish movement and location metrics. The test also showed that there was no interaction between these two factors $(p=0.179)$. Factorial ANOVAs using each of 

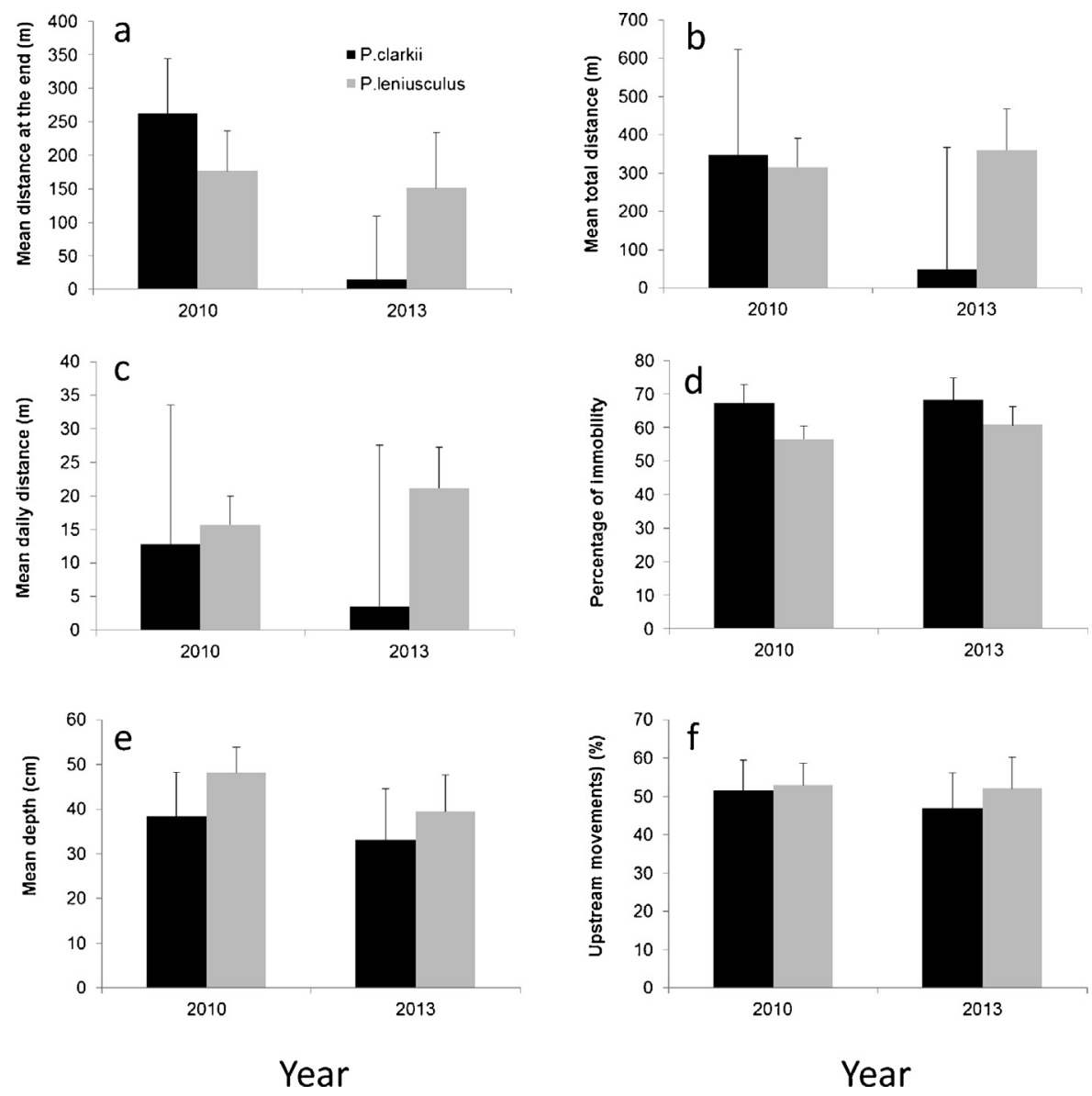

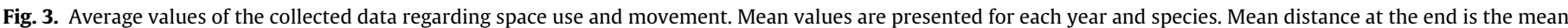

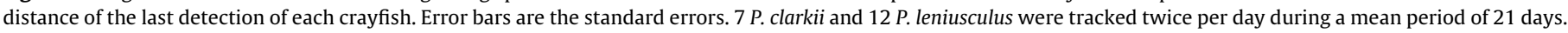
Data obtained from a total of 741 radio-location points.

the dependent variables (Table 2), found significant differences between species $(p=0.001)$, regarding the percentage of observations under vegetation cover. The maximum observed distances from the point of release were different in 2010 and $2013(p<0.05)$. Actually, contrary to 2010, in 2013 P. clarkii always remained in the vicinity of the release point. This resulted in a significant interaction $(p<0.05)$ between species and year in what concerns the maximum observed distance from the point of release.

As expected, crayfish movements were mainly oriented on an upstream/downstream axis (Fig. 3f), with minor movements perpendicular to the river. Consequently, Rao's spacing test showed that movements were not randomly distributed in all directions for either of the two species (Fig. 6).

\subsection{Upstream vs. downstream movements}

The proportion of upstream or downstream movements was independent of the species (Chi-squared test, $X^{2}=0.195$, d.f. $=1, p=0.659$ ). In fact, both species have a proportion of upstream/downstream movements not differing from 1/1 (Chisquared test; $P$. clarkii, $X^{2}=2.042$, d.f. $=1, p=0.153$; $P$. leniusculus, $X^{2}=1.843$, d.f. $\left.=1, p=0.175\right)$. The values obtained from the movement consistency indices ( $I_{\text {dir }}$ and $I_{\text {dist }}$, Figs. 4 and 5 ) showed a large interindividual variation, with some values close to 1 indicating a high consistency and other values close to zero, indicating lack of consistency. Mean $I_{\mathrm{dir}}$ was 0.4 and 0.49 for $P$. clarkii and P. leniusculus, respectively and mean $I_{\text {dist }}$ was 0.58 and 0.65 also for $P$. clarkii and $P$. leniusculus, respectively.

\subsection{Space use and mesohabitat preferences}

Considering data from both years, $P$. clarkii individuals were located at a mean depth of $36.2 \mathrm{~cm}$ (min: 17.6; max: 60.7) and P. leniusculus at a mean depth of $45.2 \mathrm{~cm}$ (min: 22.8; max: 87.3) (Fig. 3f). Figs. 7 and 8 show that crayfish occupied a small portion of the available space for a period of time and then moved to another small area. This behavior was more pronounced for $P$. leniusculus than for $P$. clarkii. The average 50th percentile areas of the kernel densities obtained with Fishtracker were $1232 \mathrm{~m}^{2}$ (min: 153; max: 3252 ) and $1519 \mathrm{~m}^{2}$ (min: 275; max: 3298) for P. clarkii and P. leniusculus, respectively. The average size of the 90th percentile kernel density areas were $2087 \mathrm{~m}^{2}$ (min: 282; max: 5733) and $2719 \mathrm{~m}^{2}$ (min: 488; max: 5949) for P. clarkii and P. leniusculus, respectively.

To assess habitat preferences, we applied the Ivlev's Electivity Index and the Standardized Forage Ratio. Both indices presented similar results (Fig. 9) with P. clarkii showing a preference for pool areas with riparian vegetation cover while $P$. leniusculus preferred riffle and pool areas with riparian vegetation cover. Both species clearly avoided run areas, with or without vegetation cover and also riffle areas without cover.

\section{Discussion}

There were differences among the two species and also among the 2010 and 2013 radio-tracking periods regarding the descriptors of movement and space use. The differences between periods may actually correspond to dissimilarities in the environmental 


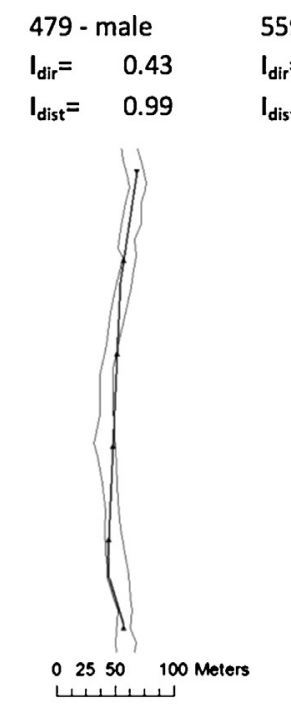

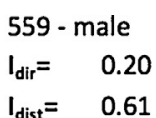

0.20

$$
0.61
$$

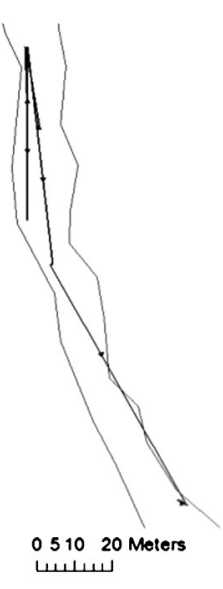

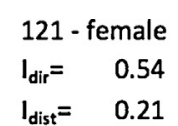

$I_{\text {dist }}=0.99$

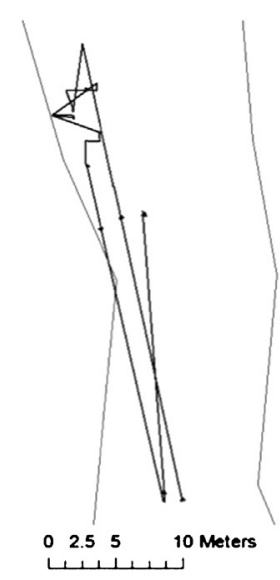

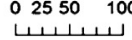

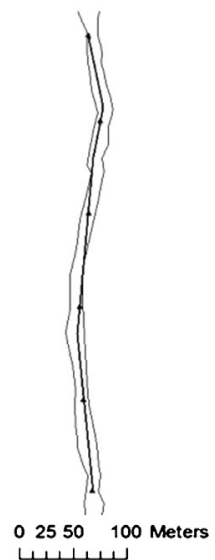

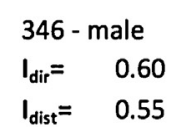

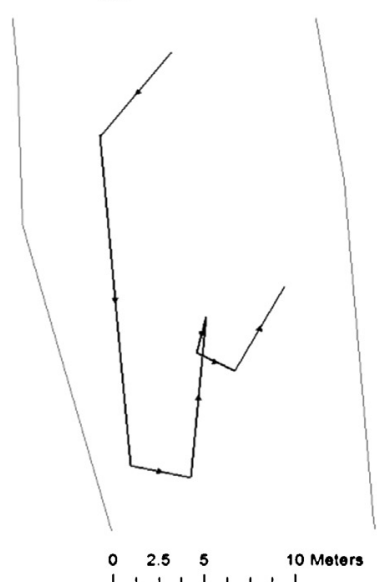

799 - female

$I_{\text {dir }}=0.25$

$I_{\text {dist }}=0.53$

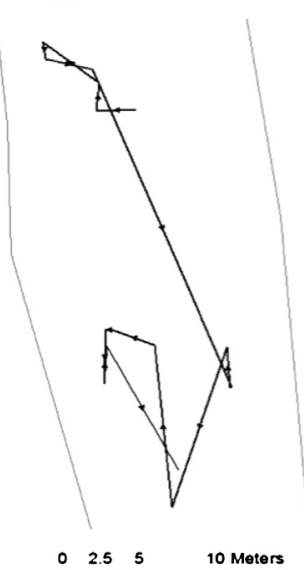

840 - female

$\mathrm{I}_{\mathrm{dir}}=0.50$

$\mathrm{I}_{\text {dist }}=0.15$

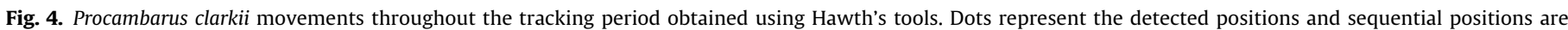

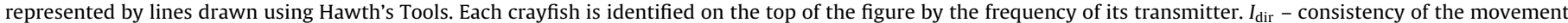
direction and $I_{\text {dist }}$ consistency of the distances moved; 0 - lack of consistency, 1 - totally consistent.

conditions, such as photoperiod, rainfall, flow, temperature or oxygen availability which can affect crayfish movement and activity (Flint, 1977; Abrahamsson, 1983; Gutierrez-Yurrita and Montes, 1998; Robinson et al., 2000; Vicky, 2000; Bubb et al., 2004). Another non-exclusive explanation would be that crayfish - all adults of approximately the same size - could possibly be at different life cycle stages. It has been described that under certain circumstances this may also affect dispersion patterns (Gherardi and Barbaresi, 2000; Light, 2003). P. clarkii main recruitment period in Portugal is usually in September/October (Anastácio and Marques, 1995; Anastácio et al., 2009) and mating is during May-July. Although no differences in reproductive form were perceptible among 2010 and 2013 individuals, the 2013 tracking period was just after the usual mating period. In wetlands areas, mating is frequently followed by burrowing, especially of females.

P. leniusculus moved more than P. clarkii (17.5 and 8.8 m day $^{-1}$, respectively) and these values are within the range presented in the literature on these species (Table 3). Using a simplified approach, i.e. assuming continuous movement in one direction without barriers or without periods of inactivity, this would be converted to $3.2 \mathrm{~km}$ year $^{-1}$ for $P$. clarkii and $6.4 \mathrm{~km} \mathrm{year}^{-1}$ for P. leniusculus. These are higher than the average values for the progression of the invasion front in the area (Bernardo et al., 2011). Possible explanations for these higher values are the absence of a perfect directionality in the movement and also the fact that the current study was performed during the summer and autumn when temperatures were warm and crayfish are more active (Araujo and Romaire, 1989; Bubb et al., 2002).

A few authors refer to the occurrence of a fright response in the first days after release of radio tagged crayfish (Robinson et al., 2000) or immediately after introduction into a new area (Fürst, 1977). Just like several other authors (Vicky, 2000; Bubb et al., 2002; Buric et al., 2009), we found no clear evidence supporting this type of behavior. Notwithstanding, we found a large interindividual variability in movement behavior for both species. This seems to be a common characteristic for several crayfish species (Flint, 1977; Robinson et al., 2000; Byron and Wilson, 2001; Bubb et al., 2002, 2006), which may indicate different “personalities" regarding the propensity for movement and dispersion, a factor which could be researched in future studies. Additionally, some studies have mentioned the possibility of coexistence of two spatial strategies, i.e. more mobile and less mobile individuals, within crayfish 


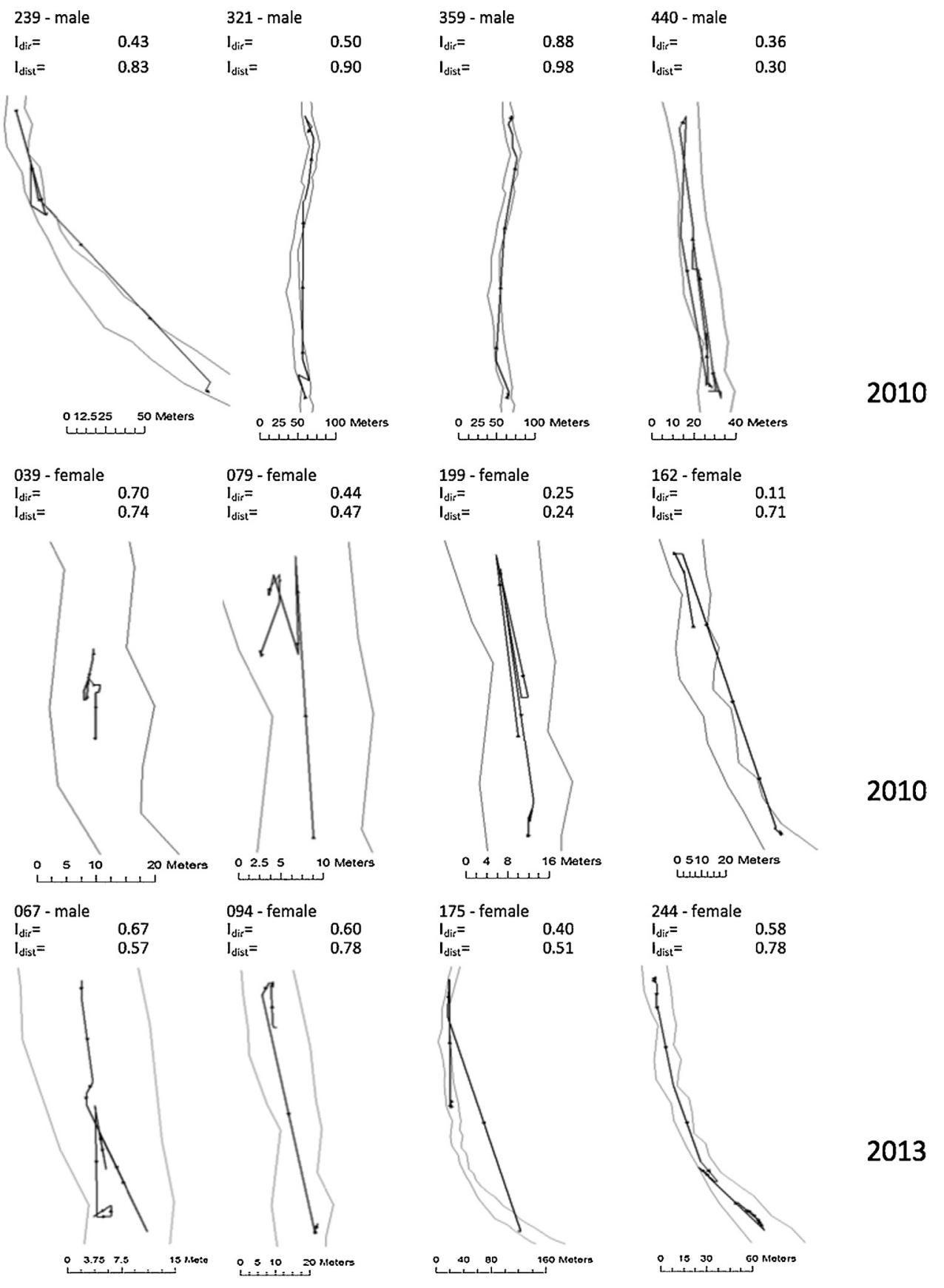

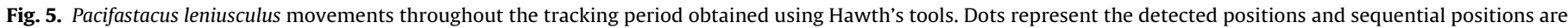

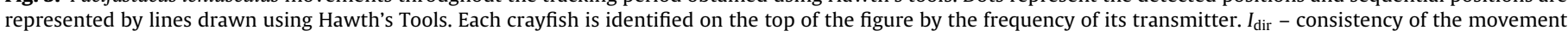
direction and $I_{\text {dist }}$ consistency of the distances moved; 0 - lack of consistency, 1 - totally consistent.

populations (Gherardi et al., 2000a,b, 2002; Gherardi and Barbaresi, 2000; Barbaresi et al., 2004). A high variability in movement strategies, when associated with small sample sizes of radio tagging studies, can eventually account for some inter-study variation in movement results.

Large-scale animal movement behavior may be advective (migratory), confined (home range) or diffusive (nomadic) (Benhamou, 2014) and the latter seems to fit the observed crayfish movement. The pattern of movement of both species often involved periods of immobility for several days, interrupted by large movements and intermittence is common in animal motion (Harnos et al., 2000; Kramer and McLaughlin, 2001). Fractal intermittence involving stops, strong re-orientations and behavioral characteristic interruptions may originate a stochastic organization of the search (for example for resources) if the animal has a low perception of the surrounding conditions (Bartumeus, 2007). This may be the case with crayfish moving on this river bed. Boulders and large stones are an important component of the substrate which strongly reduces the visual orientation capabilities of the crayfish moving on the river bottom. Moreover, due to water flow, the perception of olfactory clues may be reduced since these clues are mostly obtained from upstream sources.

Both species seemed to use a patch and then move to another, and this pattern was more pronounced in P. leniusculus. A consequence of this behavior is that it makes it inadequate to quantify true home ranges. In fact, random wandering is frequent in reptant decapods, with some staying within a home range area with no particular "home" while others are known to relocate periodically 
Table 2

Results of factorial ANOVAs, using species and year as independent variables.

\begin{tabular}{|c|c|c|c|c|c|c|}
\hline Source & Dependent variable & Type III sum of squares & df & Mean square & $F$ & Sig. \\
\hline \multirow[t]{3}{*}{ Corrected model } & $\mathrm{LOG}_{10}(\mathrm{MDD})$ & $1.159^{a}$ & 3 & .386 & 2.252 & .124 \\
\hline & $\mathrm{LOG}_{10}(\mathrm{MOD})$ & $2.617^{\mathrm{b}}$ & 3 & .872 & 3.574 & .039 \\
\hline & \%UVC & $7064.941^{\mathrm{c}}$ & 3 & 2354.980 & 5.354 & .010 \\
\hline \multirow[t]{3}{*}{ Intercept } & $\mathrm{LOG}_{10}(\mathrm{MDD})$ & 14.359 & 1 & 14.359 & 83.670 & .000 \\
\hline & $\mathrm{LOG}_{10}(\mathrm{MOD})$ & 59.280 & 1 & 59.280 & 242.846 & .000 \\
\hline & $\% U V C$ & $68,074.094$ & 1 & $68,074.094$ & 154.755 & .000 \\
\hline \multirow[t]{3}{*}{ Species } & $\mathrm{LOG}_{10}(\mathrm{MDD})$ & .590 & 1 & .590 & 3.438 & .083 \\
\hline & $\mathrm{LOG}_{10}(\mathrm{MOD})$ & .658 & 1 & .658 & 2.694 & .122 \\
\hline & \%UVC & 6798.449 & 1 & 6798.449 & 15.455 & .001 \\
\hline \multirow[t]{3}{*}{ Year } & $\mathrm{LOG}_{10}(\mathrm{MDD})$ & .196 & 1 & .196 & 1.144 & .302 \\
\hline & $\mathrm{LOG}_{10}(\mathrm{MOD})$ & 1.270 & 1 & 1.270 & 5.201 & .038 \\
\hline & $\% U V C$ & 204.035 & 1 & 204.035 & .464 & .506 \\
\hline \multirow[t]{3}{*}{ Species *year } & LOG10(MDD) & .689 & 1 & .689 & 4.017 & .063 \\
\hline & $\mathrm{LOG}_{10}(\mathrm{MOD})$ & 1.392 & 1 & 1.392 & 5.703 & .031 \\
\hline & \%UVC & 14.414 & 1 & 14.414 & .033 & .859 \\
\hline \multirow[t]{3}{*}{ Error } & $\mathrm{LOG}_{10}(\mathrm{MDD})$ & 2.574 & 15 & .172 & & \\
\hline & $\mathrm{LOG}_{10}(\mathrm{MOD})$ & 3.662 & 15 & .244 & & \\
\hline & \%UVC & 6598.237 & 15 & 439.882 & & \\
\hline \multirow[t]{3}{*}{ Total } & $\mathrm{LOG}_{10}(\mathrm{MDD})$ & 21.732 & 19 & & & \\
\hline & $\mathrm{LOG}_{10}(\mathrm{MOD})$ & 79.531 & 19 & & & \\
\hline & \%UVC & $81,178.060$ & 19 & & & \\
\hline \multirow[t]{3}{*}{ Corrected total } & $\mathrm{LOG}_{10}(\mathrm{MDD})$ & 3.733 & 18 & & & \\
\hline & $\mathrm{LOG}_{10}(\mathrm{MOD})$ & 6.279 & 18 & & & \\
\hline & \%UVC & $13,663.178$ & 18 & & & \\
\hline
\end{tabular}

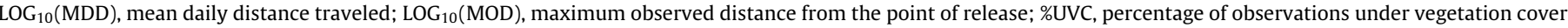

${ }^{\mathrm{a}} \mathrm{R}$ squared $=.311$ (adjusted $\mathrm{R}$ squared $=.173$ ).

b $\mathrm{R}$ squared $=.417$ (adjusted $\mathrm{R}$ squared $=.300$ ).

c $\mathrm{R}$ squared $=.517$ (adjusted $\mathrm{R}$ squared $=.420$ ).

(Vannini and Cannicci, 1995). Indeed, Robinson et al. (2000) referred to this as ephemeral home ranges and one consequence of this wandering behavior is that the longer a crayfish is followed by radio-tracking, the larger the "home range" recorded (Hazlett et al., 1974).

Lévy Walk is a form of Simple Random Walk in which turn and orientation distributions are uniformly random, with a heavy tailed step length distribution (Benhamou, 2014). Lévy processes of movement can be described by random walk models and among the latter there are Lévy flight and Lévy walk models. With large time scales in comparison to the duration of movement, a Lévy flight approach is more adequate. However, in the present study, the duration of the movements is relevant and therefore Lévy walk should provide a superior approximation when modeling crayfish movement. As these two species are currently expanding their distribution in the area (Bernardo et al., 2011), our results offer valuable information for modeling and consequently for managing their spread.
The developed indices $\left(I_{\mathrm{dir}}\right.$ and $\left.I_{\mathrm{dist}}\right)$ showed large interindividual variations in the consistency of the direction of movement but no species specific tendencies were noted. Most of the half-day movements detected in both species are on an upstream/downstream axis and this is likely due to the almost linear structure of the river channel. In fact, lateral movement of the crayfish is limited by the narrow river channel. The low flow during the periods of the year when field work took place may be one of the reasons why the proportions of upstream/downstream movements did not differ from $1 / 1$. Similar proportions of upstream/downstream movements were also found for other crayfish species (Robinson et al., 2000; Bubb et al., 2002; Kadlecová et al., 2012) as well as for P. clarkii (Kerby et al., 2005) but results are mixed for $P$. leniusculus, with some authors finding some directionality in the movement along the river (Holdich et al., 1995; Guan and Wiles, 1997; Buřič, 2009).

The comparison of the two habitat preference indices confirms the notion that although Ivlev's Electivity Index (Ivlev, 1961)

Table 3

Movement speed of $P$. clarkii and $P$. lenisculus presented in the literature.

\begin{tabular}{|c|c|c|}
\hline Species & Speed $\left(\mathrm{m} \mathrm{day}^{-1}\right)$ & References \\
\hline P. clarkii & $1.1-4.6$ & Gherardi et al. (2000a) \\
\hline P. clarkii & Maximum of 4000 (in rice field habitats) & Gherardi and Barbaresi (2000) \\
\hline P. clarkii & $0.6-1.5$ & Gherardi et al. (2000b) \\
\hline P. clarkii & $1-11$ (temporary stream) & Gherardi et al. (2002) \\
\hline P. clarkii & $2.5-38$ & Aquiloni et al. (2005) \\
\hline \multirow[t]{2}{*}{ P. leniusculus } & 13.5 upstream & Bubb et al. (2004) \\
\hline & 15 downstream & \\
\hline P. leniusculus & 5 (approximate median) & Bubb et al. (2006b) \\
\hline P. leniusculus & Maximum of 600 (Introduction in a new area) & Fürst (1977) \\
\hline P. leniusculus & 3.29 (downstream colonization rate) & Peay and Rogers (1998) \\
\hline P. leniusculus & 4.1 & Holdich (1991) \\
\hline \multirow[t]{2}{*}{ P. leniusculus } & 7.7 (downstream colonization rate) & Bernardo et al. (2011) \\
\hline & 4.6 (upstream colonization rate) & \\
\hline
\end{tabular}



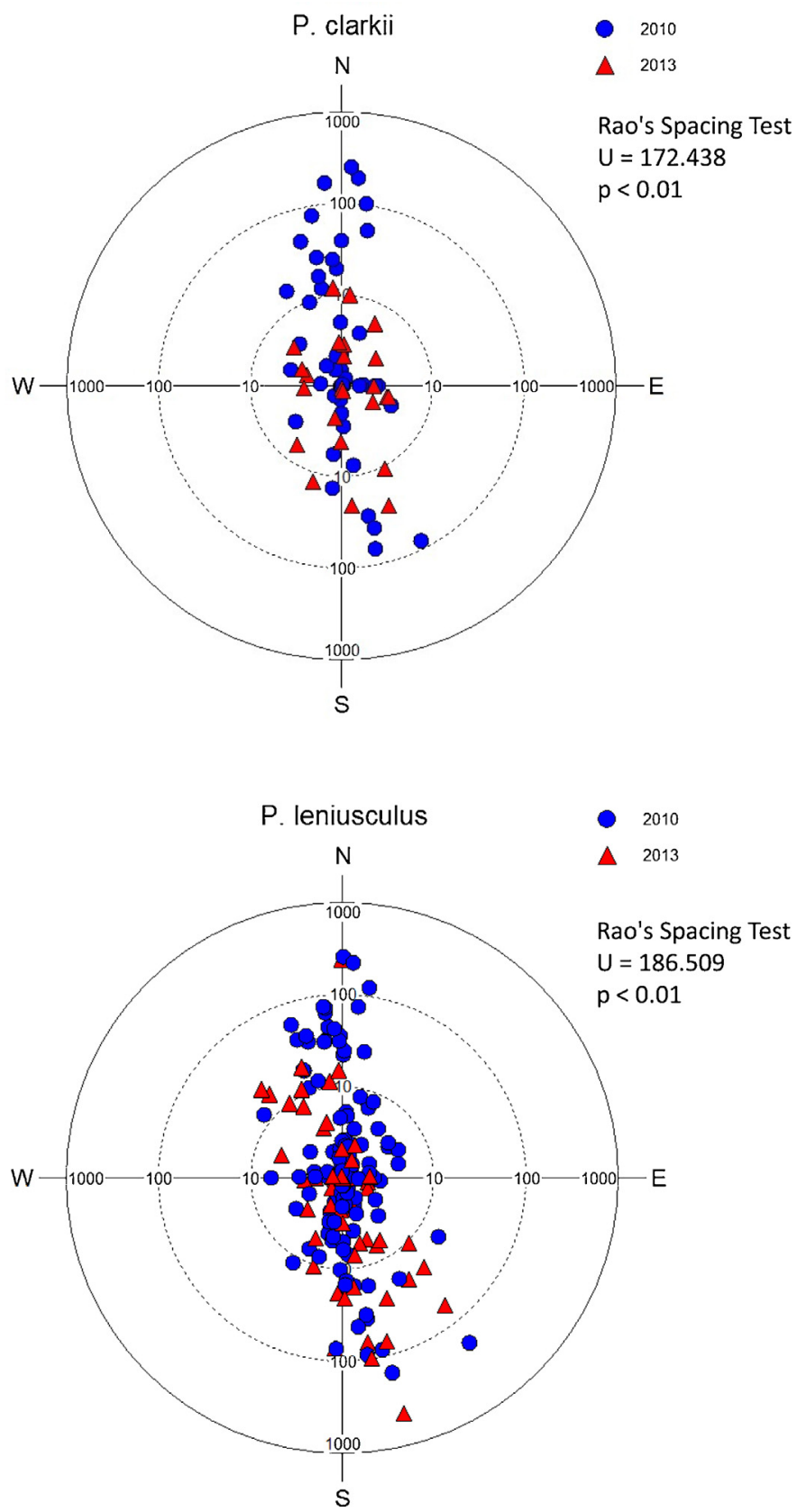

Fig. 6. Circular plot of all the data obtained during 2010 and 2013 regarding the directions and the respective distances moved. Top figure $-P$. clarkii. Bottom figure - P. leniusculus. A logarithmic scale of $0-1000 \mathrm{~m}$ is used. The results of the Rao's spacing test for randomness of directions are presented ( $U$ statistic and $p$ value).

is widely used, the Standardized Forage Ratio is more robust (Chesson, 1983) and provides a clearer picture of the habitat preferences. The finding that $P$. clarkii prefers pool areas with vegetation cover is in accordance with previous work (Aquiloni et al., 2005; Banha and Anastácio, 2011). Actually, P. clarkii is mostly a lowland aquatic species and needs the right type of sediment to build burrows (Correia and Ferreira, 1995), while P. leniusculus is highly adapted to living in mountain rivers, as observed in the Iberian Peninsula (Rallo and García-Arberas, 2002). In our study in the river Maçãs, $P$. leniusculus showed a stronger preference for riffle than for pool areas, both with riparian vegetation cover. These results are somewhat different from results obtained in lake and reservoir areas within the native distribution, in which the adults

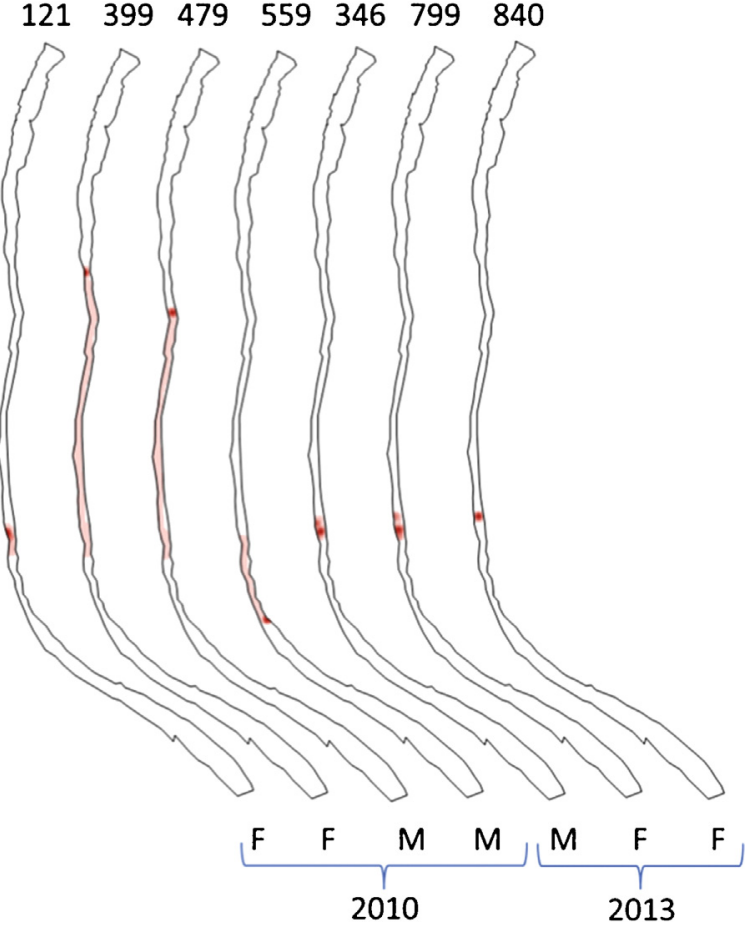

Fig. 7. Kernel density plots for Procambarus clarkii. The red color indicates the areas with a higher intensity of use for each individual. Each crayfish is identified by the frequency of its transmitter. $\mathrm{M}$ - male; F - female. (For interpretation of the references to color in this text, the reader is referred to the web version of the article.)

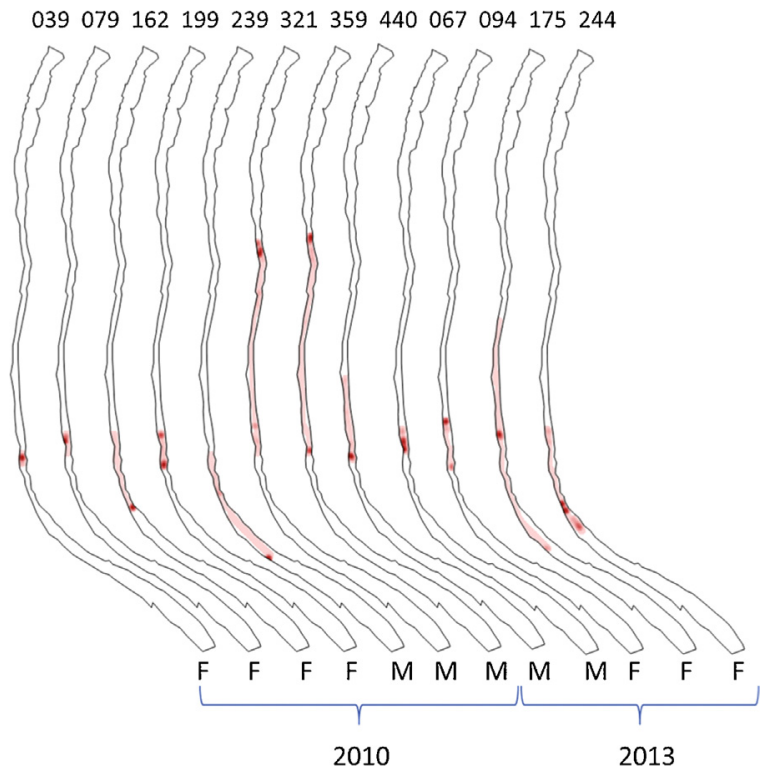

Fig. 8. Kernel density plots for Pacifastacus leniusculus. The red color indicates the areas with a higher intensity of use for each individual. Each crayfish is identified by the frequency of its transmitter. $\mathrm{M}$ - male; $\mathrm{F}$ - female. (For interpretation of the references to color in this text, the reader is referred to the web version of the article.)

of this species prefer deep, sandy and less vegetated areas (e.g. Abrahamsson and Goldman, 1970; Lewis and Horton, 1997).

Both species avoided run areas, with or without vegetation cover and also riffle areas without cover. Spatial displacement mechanisms due to one of the species having an advantage in aggressive encounters, e.g. while competing for shelter, do not seem to be sustained by previous experimental approaches involving $P$. clarkii 

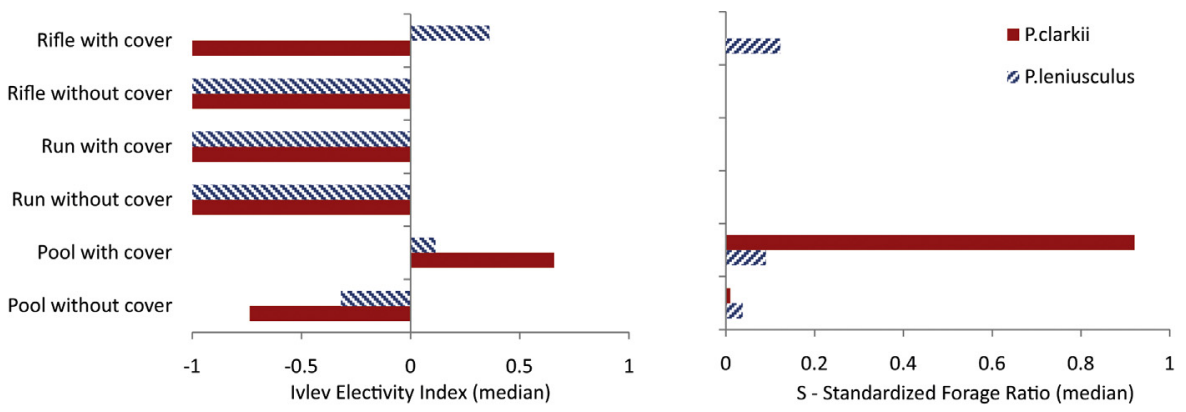

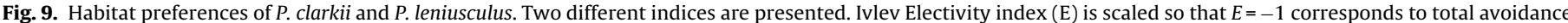

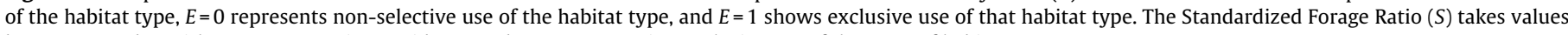
between 0 and 1 , with $S=0$ representing avoidance and $S=1$ representing exclusive use of that type of habitat.

and P. leniusculus (Mueller and Bodensteiner, 2009). Coexistence at a small scale was in fact observed in this study, with non-tagged crayfish of both species often being visually detected in the same area.

It was possible to identify a few limitations in our approach. Our data do not allow for an analysis of the annual patterns of variation in the movement and space use. Since the study was conducted in two restricted periods, with different individuals in each period, there was also no possibility of assessing the effects of environmental variables (e.g. temperature). The values of the environmental variables were actually quite conservative throughout the study. We consider that our results reflect a maximum dispersion of these species in the area since the study was performed during the periods of largest crayfish activity. Due to the large effort involved in radio-tracking studies, we could not make a direct comparison of a situation with and without co-occurrence of crayfish species. In spite of this, in other species of crayfish such as Austropotamobius torrentium, the spread is dependent on the occurrence of A. astacus (Kadlecová et al., 2012). From our results it is clear that neither of the species stops its activity due to the presence of the competing species.

In addition, we were unable to clearly distinguish night and day movements since all the observations were made during daytime, according to the 12-h interval that was used. Although crayfish are usually highly nocturnal, in previous work the proportion of daytime movements was shown to be significantly greater in summer months than in autumn months (Johnson et al., 2014).

$P$. clarkii is currently established throughout almost all of the Iberian Peninsula (Souty-Grosset et al., 2006) but is still spreading toward some headwater streams. Additionally, it is spreading strongly in other European territories (e.g. Italy; (Scalici et al., 2010)) and there are still wide areas environmentally suitable for invasion worldwide (Capinha et al., 2011). Likewise, P. leniusculus is spreading over the Iberian Peninsula, with wide areas available for invasion in this territory and also worldwide (Capinha et al., 2011, 2012). On a macroscale, these two species have relatively different environmental preferences but their distributions clearly overlap in some areas, such as the studied river stretch. Our work provided new and valuable data for modeling the dispersion of these two species in a context of coexistence.

\section{Acknowledgements}

We thank the anonymous reviewers who gave valuable contributions for improving this paper. This study was partially financed by FEDER funds through the "Programa Operacional de Factores de Competitividade - COMPETE" and by national funds through "FCT - Fundação para a Ciência e Tecnologia" within the scope of the project DID (Dispersal of Invasive Decapoda)(PTDC/BIA-BEC/105182/2008). Instituto da Conservação da Natureza e das Florestas also provided financial support. Filipe Banha holds a PhD grant from FCT (SFRH/BD/81378/2011) and César Capinha acknowledges funding support from FCT (grants SFRH/BD/41129/2007 and SFRH/BPD/84422/2012).

\section{References}

Abrahamsson, S., 1973. Methods for restoration of crayfish waters in Europe. The development of an industry for production of young of Pacifastacus leniusculus Dana. Freshw. Crayfish 3, 203-210.

Abrahamsson, S., 1983. Trappability, locomotion, and diel pattern of activity of the crayfish Astacus astacus and Pacifastacus leniusculus Dana. Freshw. Crayfish 5 239-253.

Abrahamsson, S.A., Goldman, C.R., 1970. Distribution, density and production of the crayfish Pacifastacus leniusculus Dana in Lake Tahoe, California-Nevada. Oikos 21, 83-91.

Almeida, D. Ellis, A., England, J., Copp, G.H., 2013. Time-series analysis of native and non-native crayfish dynamics in the Thames River Basin (southeastern England). Aquat. Conserv.: Mar. Freshw. Ecosyst., http://dx.doi.org/ 10.1002 /aqc. 2366.

Anastácio, P.M., Marques, J.C., 1995. Population biology and production of the red swamp crayfish Procambarus clarkii (Girard) in the lower Mondego river valley, Portugal. J. Crust. Biol. 15, 156-168.

Anastácio, P.M., Leitão, A.S., Boavida, M.J., Correia, A.M., 2009. Population dynamics of the invasive crayfish (Procambarus clarkii Girard, 1852) at two marshes with differing hydroperiods. Ann. Limnol. 45, 247-256, http://dx.doi.org/10.1051/ $\operatorname{limn} / 2009025$.

Aquiloni, L., Ilheu, M., Gherardi, F., 2005. Habitat use and dispersal of the invasive crayfish Procambarus clarkii in ephemeral water bodies of Portugal. Mar. Freshw. Behav. Physiol. 38, 225-236.

Araujo, M.A., Romaire, R.P., 1989. Effects of water quality, weather and lunar phase on crawfish catch. J. World Aquac. Soc. 20, 199-207.

Banha, F., Anastácio, P.M., 2011. Interactions between invasive crayfish and native river shrimp. Knowl. Manag. Aquat. Ecosyst. 401, 1-12, http://dx.doi.org/10. 1051/kmae/2011033.

Barbaresi, S., Santini, G., Tricarico, E., Gherardi, F., 2004. Ranging behaviour of the invasive crayfish, Procambarus clarkii (Girard). J. Nat. Hist. 38, 2821-2832.

Bartumeus, F., 2007. Lévy processes in animal movement: an evolutionary hypothesis. Fractals 15, 151-162.

Benhamou, S., 2014. Of scales and stationarity in animal movements. Ecol. Lett. 17 261-272, http://dx.doi.org/10.1111/ele.12225.

Bernardo, J.M., Costa, A.M., Bruxelas, S., Teixeira, A., 2011. Dispersal and coexistence of two non-native crayfish species (Pacifastacus leniusculus and Procambarus clarkii) in NE Portugal over a 10-year period. Knowl. Manag. Aquat. Ecosyst. $401,28$.

Beyer, H.L., 2004. Hawth's Analysis Tools for ArcGIS, http://www.spatialecology com/htools

Bubb, D.H., Lucas, M.C., Thom, T.J., 2002. Winter movements and activity of signal crayfish Pacifastacus leniusculus in an upland river, determined by radio telemetry. Hydrobiologia 483, 111-119.

Bubb, D.H., Thom, T.J., Lucas, M.C., 2004. Movement and dispersal of the invasive sig nal crayfish Pacifastacus leniusculus in upland rivers. Freshw. Biol. 49, 357-368.

Bubb, D.H., Thom, T.J., Lucas, M.C., 2006a. Movement patterns of the invasive signal crayfish determined by PIT telemetry. Can. J. Zool. 84, 1202-1209.

Bubb, D.H., Thom, T.J., Lucas, M.C., 2006b. Movement, dispersal and refuge use of co-occurring introduced and native crayfish. Freshw. Biol. 51, 1359-1368.

Buřič, M., 2009. Biology of Spiny-cheek Crayfish (Orconectes limosus, Rafinesque, 1817) Under Conditions of the Czech Republic and the Study of Factors Influencing its Invasive Spreading. University of South Bohemia, České Budějovice.

Buric, M., Kozák, P., Kouba, A., 2009. Movement patterns and ranging behavior of the invasive spiny-cheek crayfish in a small reservoir tributary. Fundam. Appl. Limnol. 174, 329-337. 
Byron, C.J., Wilson, K.A., 2001. Rusty crayfish (Orconectes rusticus) movement within and between habitats in Trout Lake, Vilas County, Wisconsin. J. N. Am. Benthol. Soc. 20, 606-614.

Capinha, C., Anastácio, P., 2011. Assessing the environmental requirements of invaders using ensembles of distribution models. Divers. Distrib. 17, 13-24, http://dx.doi.org/10.1111/j.1472-4642.2010.00727.x.

Capinha, C., Leung, B., Anastácio, P., 2011. Predicting worldwide invasiveness for four major problematic decapods: an evaluation of using different calibration sets. Ecography 34, 448-459, http://dx.doi.org/10.1111/j.1600-0587.2010.06369.x.

Capinha, C., Anastácio, P., Tenedório, J., 2012. Predicting the impact of climate change on the invasive decapods of the Iberian inland waters: an assessment of reliability. Biol. Invasions 14, 1737-1751, http://dx.doi.org/10.1007/s10530 012-0187-z.

Capinha, C., Brotons, L., Anastácio, P., 2013. Geographical variability in propagule pressure and climatic suitability explain the European distribution of two highly invasive crayfish. J. Biogeogr. 40, 548-558, http://dx.doi.org/10.1111/jbi.12025.

Chesson, J., 1983. The estimation and analysis of preference and its relatioship to foraging models. Ecology 64, 1297-1304.

Correia, M.A., Ferreira, O., 1995. Burrowing behavior of the introduced red swamp crayfish Procambarus clarkii (Decapoda: Cambaridae) in Portugal. J. Crust. Biol. 15 (2), 248-257.

Flint, R.W., 1977. Seasonal activity, migration and distribution of crayfish, Pacifastacus leniusculus, in lake Tahoe. Am. Midl. Nat. 97, 280-292.

Fürst, M., 1977. Introduction of Pacifastacus leniusculus (Dana) into Sweden: methods, results and management. Freshw. Crayfish 3, 229-247.

Gherardi, F., 2006. Crayfish invading Europe: the case study of Procambarus clarkii. Mar. Freshw. Behav. Physiol. 39, 175-191.

Gherardi, F., 2013. Crayfish as global invaders: distribution impact on ecosystem services and management options. Freshw. Crayfish 19, 177-187.

Gherardi, F., Barbaresi, S., 2000. Invasive crayfish: activity patterns of Procambarus clarkii in the rice fields of the Lower Guadalquivir (Spain). Arch. Hydrobiol. 150 153-168.

Gherardi, F.G., Holdich, D.M., 1999. Crayfish in Europe as Alien Species: How to Make the Best of a Bad Situation?, vol. 11. CRC Press Ltd

Gherardi, F., Acquistapace, P., Tricarico, E., Barbaresi, S., 2000a. Ranging and burrowing behaviour of the red swamp crayfish in an invaded habitat: the onset of hibernation. Freshw. Crayfish 13, 330-337.

Gherardi, F., Raddi, A., Barbaresi, S., Salvi, G., 2000b. Life history patterns of the red swamp crayfish (Procambarus clarkii) in an irrigation ditch in Tuscany, Italy. In: Von Vaupel Klein, J.C., Schram, F.R. (Eds.), The Biodiversity Crisis and Crustacea. Crustacean Issues, vol. 12. Balkema, pp. 99-108.

Gherardi, F., Tricarico, E., Ilhéu, M.A., 2002. Movement patterns of an invasive crayfish, Procambarus clarkii, in a temporary stream of southern Portugal. Ethol. Ecol. Evol. 14, 183-197.

Guan, R.-Z., Wiles, P., 1997. The home range of the signal crayfish in a British lowland river. Freshw. Forum 8, 45-54.

Gutierrez-Yurrita, P.J., Montes, C., 1998. Environmental factors controlling crayfish Procambarus clarkii activity in the Donana National Park freshwater marsh (SWSpain). Comp. Biochem. Physiol. A - Mol. Integr. Physiol. 120, 713-721.

Habsburgo-Lorena, A.S., 1978. Present situation of exotic species of crayfish introduced into spanish continental waters. Freshw. Crayfish 4, 175-184.

Harnos, A., Horvath, G., Lawrence, A., Vattay, G., 2000. Scaling and intermittency in animal behaviour. Phys. A: Stat. Mech. Appl. 286, 312-320.

Hazlett, B., Rittschof, D., Rubenstein, D., 1974. Behavioral biology of the crayfish Orconectes virilis I. Home range. Am. Midl. Nat., 301-319.

Henttonen, P., Huner, J.V., 1999. The introduction of alien species of crayfish in Europe: a historical introduction. In: Gherardi, F., Holdich, D. (Eds.), Crayfish in Europe as Alien Species. Crustacean Issues, vol. 11. Balkema, Roterdam, pp. $13-21$.

Holdich, D.M., 1988. The dangers of introducing alien animals with particular reference to crayfish. Freshw. Crayfish 7, 15-30.

Holdich, D., 1991. The native crayfish and threats to its existence. British Wildlife 2, $141-151$.

Holdich, D.M., Rogers, W.D., Reader, J.P., 1995. Crayfish Conservation. National Rivers Authority, Bristol, UK.

Holdich, D.M., Reynolds, J.D., Souty-Grosset, C., Sibley, P.J., 2010. A review of the ever increasing threat to European crayfish from non-indigenous crayfish species. Knowl. Manag. Aquat. Ecosyst. 11, 394-395.
Ivlev, V.S., 1961. Experimental Ecology of the Feeding of Fishes. Yale University Press, New Haven.

Johnson, M., Rice, S., Reid, I., 2014. The activity of signal crayfish (Pacifastacus leniusculus) in relation to thermal and hydraulic dynamics of an alluvial stream, UK. Hydrobiologia 724, 41-54, http://dx.doi.org/10.1007/s10750-013-1708-1.

Kadlecová, K., Bily, M., Maciak, M., 2012. Movement patterns of the co-occurring species Astacus astacus (noble crayfish) and Austropotamobius torrentium (stone crayfish). Fundam. Appl. Limnol. 180, 351-360.

Kerby, J.L., Riley, S.P.D., Kats, L.B., Wilson, P., 2005. Barriers and flow as limiting factors in the spread of an invasive crayfish (Procambarus clarkii) in southern California streams. Biol. Conserv. 126, 402-409.

Kramer, D.L., McLaughlin, R.L., 2001. The behavioral ecology of intermittent locomotion. Am. Zool. 41, 137-153.

Laffan, S.W., Taylor, M.D., 2013. FishTracker: a GIS toolbox for kernel density estimation of animal home ranges that accounts for transit times and hard boundaries. In: Paper Presented at the 20th International Congress on Modelling and Simulation, Adelaide, Australia, 1-6 December 2013.

Laurent, P.J., 1997. Crayfish introductions into France and in the world, history and consequences. Bull. Fr. Peche Piscicult., 345-356.

Lewis, S., 2002. Pacifastacus. In: Holdich, D. (Ed.), Biology of Freshwater Crayfish. Blackwell, Oxford, pp. 511-540.

Lewis, S.D., Horton, H.F., 1997. Life history and population dynamics of the signal crayfish, Pacifastacus leniusculus, in Lake Billy Chinook, Oregon. Freshw. Crayfish $11,34-53$.

Light, T., 2003. Success and failure in a lotic crayfish invasion: the roles of hydrologic variability and habitat alteration. Freshw. Biol. 48, 1886, http://dx.doi.org/ 10.1046/j.1365-2427.2003.01122.x.

Loughman, Z.J., Skalican, K.T., Taylor, N.D., 2013. Habitat selection and movement of Cambarus chasmodactylus (Decapoda: Cambaridae) assessed via radio telemetry. Freshw. Sci. 32, 1288-1297.

Lowery, R., Holdich, D., 1988. Pacifastacus leniusculus in North America and Europe, with details of the distribution of introduced and native crayfish species in Europe. In: Holdich, D., Lowery, R. (Eds.), Freshwater Crayfish: Biology, Management and Exploitation. Croom Helm, London, pp. 283-308.

Meals, D.W., Dressing, S.A., 2008. Surface Water Flow Measurement for Water Quality Monitoring Projects, March 2008, Tech Notes, vol. 3. Fairfax, VA, USA, pp. $1-16$.

Mueller, K.W., Bodensteiner, L.R., 2009. Shelter occupancy by mixed-species pairs of native signal crayfish and non-native red swamp crayfish held in enclosures. J. Freshw. Ecol. 24, 67-76.

Newson, M.D., Newson, C.L., 2000. Geomorphology, ecology and river channel habitat: mesoscale approaches to basin-scale challenges. Prog. Phys. Geogr. 24, 195-217, http://dx.doi.org/10.1177/030913330002400203.

Nyström, P., 1999. Ecological impact of introduced and native crayfish on freshwater communities: European perspectives. In: Gherardi, F., Holdich, D.M. (Eds.) Crayfish in Europe as Alien Species - How to Make the Best of a Bad Situation? Crustacean Issues, vol. 11. Balkema, Rotterdam, pp. 63-85.

Peay, S., Rogers, D., 1998. The peristaltic spread of signal crayfish (Pacifastacus leniusculus) in the River Wharfe, Yorkshire, England. Freshw. Crayfish 12, 665-676.

Rallo, A., García-Arberas, L., 2002. Differences in abiotic water conditions between fluvial reaches and crayfish fauna in some northern rivers of the Iberian Peninsula. Aquat. Living Resour. 15, 119-128, http://dx.doi.org/10.1016/ S0990-7440(02)01156-7.

Robinson, C.A., Thom, T.J., Lucas, M.C., 2000. Ranging behaviour of a large freshwater invertebrate, the white-clawed crayfish Austropotamobius pallipes. Freshw. Biol. 44, 509-521.

Scalici, M., Pitzalis, M., Gibertini, G., 2010. Crayfish distribution updating in central Italy. Knowl. Manag. Aquat. Ecosyst. 394, 06.

Souty-Grosset, C., Holdich, D., Noel, P.Y., Reynolds, J.D., Haffner, P., 2006. Atlas of Crayfish in Europe. Muséum National d'Histoire Naturelle, Paris.

Vannini, M., Cannicci, S., 1995. Homing behaviour and possible cognitive maps in crustacean decapods. J. Exp. Mar. Biol. Ecol. 193, 67-91.

Vicky, A., 2000. Observations of radio tracked crayfish (Austropotamobius pallipes) in a northern British river. Crayfish Conference Leeds, vol. 26. pp. 58-64.

Westman, K., 1973. Cultivation of the American crayfish Pacifastacus leniusculus. Freshw. Crayfish 3, 211-220. 